J.H. Gaudy MD, J.F. Sicard MD, F, Lhoste MD, J.F. Boitier MD

\title{
The effects of cremophor EL in the anaesthetized dog
}

The effects of cremophor EL were studied in 13 anassthetized, paralyzed and ventilated dogs. Twenty per cent cremophor EL in a dose of $4.3 \pm 0.92 \mathrm{ml}$ was infused ar a rate of $30 \mathrm{ml} \cdot \mathrm{hr}^{-1}$. In seven dogs, thoracopulmonary compliance, heart rate, systemic arterial pressure (SAP), pulmonary pressures ( $P A P, P C W P$, $R A P)$, cardiac output ( $C O$ ) and platelet and white cell counts, were measured before the injection of cremophor $E L$, at the end of infusion and $5,10,30$ and 150 minutes after the end of infusion. In six dogs, SAP, CO, and blood volume were measured before the injection of cremophor $E L$, at the end of infusion and 10,30,90 and 150 minutes after the end of infusion. Plasma histamine and catecholamines were assayed before the injection of cremophor EL and 2, 5, 10,30,90 and 150 mintutes after stariing the infusion.

Cremophor EL induced a marked, susiained and significant decrease in SAP at the end of infusion and at 5, 10 and 30 minutes after the completion of the infusion $(-68,-71,-70$ and -43 per cent respectively), in PCWP, RAP and CO $(-78$ per cent at the end of infusion, -32 per cent 150 minutes after the end of infusion). Heart rate and systemic vascular resistance did not vary significantly. Pulmonary vascular resistance increased at the end of infusion, five and ten mirutes after the end of infusion $(+7,34,+548$ and +439 per cent respectiveiy). Plasma volume decreased 10 and 30 minutes after the end of infusion ( -28 and -30.5 per cent respectively). Tharacopulmonary compliance decreased $(-46$ per cent at the end of infusion). Platelet and white cell counts decreased markedly. There was a marked and sustained increase in plasma hista-

\section{Key words}

PHARMACOLOGY: cremophor EL; COMPLICATIONS: anaphylaxis, anaphylactoid reaction; CARDIOVASCULAR SYSTEM: cremophor EL.

From the Département d'Anesthésie-Réanimation, Hôpital Rothschild, Paris (J.H.G. J.F.B.), the Département d'Anesthésje-Réanimation, Hôpital Tenon, Paris (J.F.S.) and the Département de Pharmacologie Clinique, Hôpital Henri Mondor, Créteil (F.L.).

Address correspondence 1o: Professeur J.H. Gaudy, Département d'Anesthésie-Réanimation, Hôpital Rothschild, 33, bd de Picpus, 75012, Paris, France. mine $(+1214$ per cent 10 minutes after start of infusion) and in plasma epinephrine and norepinephrine. In six dogs cutaneous erythema and oedema of the paws and of the muzzle were present.

These findings are very similar to the observations reported in man during anaphylactoid andlor anaphylactic reactions. This model could be used in studying anaphylactoid reactions and their prevention and trearment.

Anaphylactic and/or anaphylactoid reactions are being reported with increasing frequency in the anaesthesia literature. Reviews and monographs have been devoted to this subject. ${ }^{1-5}$ The mechanisms of these reactions remain controversial, ${ }^{6}$ and prevention and treatment are poorly defined. Numerous anaesthetic agents are able to induce such reactions, particularly propanidid and althesin which are dissolved in cremophor EL (polyoxyethylenated castor oil). The effects of cremophor EL have not been extensively studied in animals or in man. Studies have been restricted to haemodynamic effects (arterial hypotension) and to histamine release in the pig and the dog. ${ }^{8}$ The present study was undertaken to examine in the dog the effects of intravenous injection of cremophor EL on systemic and pulmonary haemodynamics, the respiratory system, blood volume, white cells and platelets, histamine and catecholamine release, and to compare these effects to the anaphylactoid or anaphylactic reactions reported in man.

The study was carried out in 13 male beagle dogs (mean weight $\pm \mathrm{SD}=13.2 \pm 1.5 \mathrm{~kg}$ ) fasted for 12 hours. Each animal was placed on a thermostatically controlled mattress, with rectal temperature being maintained at $38 \pm 0.5^{\circ} \mathrm{C}$. A foreleg vein was cannulaled and anaesthesia was induced with thiopentone IV (20 $\mathrm{ng} \mathrm{kg}^{-1}$ ). The trachea was intubated and ventilation was controlled artificially $\left(\mathrm{FIO}_{2}=1.00\right)$. Respiratory frequency was fixed at $12 / \mathrm{min}$ and tidal volume was adjusted to produce an end-tidal carbon dioxide concentration of $5 \pm 0.5$ per cent, which was monitored using an infrared analyser. The animals were paralyzed with $0.5 \mathrm{mg} \cdot \mathrm{kg}^{-1}$ (total dose) of pancuronium. Anaesthesia was maintained with halothane (inspiratory concentration 1.0 per cent). A femoral catheter was inserted to record systemic arterial 
pressure and collect blood samples. A Swan-Ganz thermodilution catheter (SF) was placed in an external jugular vein and its tip was placed distally in a pulmonary artery with the aid of oscilloscopic display of the blood pressure curve. Twenty per cent cremophor EL (the concentration used in althesin) was infused through a peripheral vein at a constant speed $\left(30 \mathrm{ml} \cdot \mathrm{hr}^{-1}\right)$. The infusion of cremophor was stopped when systolic arterial pressure decreased by more than 50 per cent of control.

The animals were divided into two groups. In the first group (Group I, $\mathrm{n}=7$ ), tracheal pressure, respiratory flow and tidal volume were continuously recorded. Heart rate, systemic arterial pressure, pulmonary arterial pressure, pulmonary capillary wedge pressure, right atrial pressure, cardiac output, plate]et and white cell counts, were measured before the injection of cremophor EL, at the end of infusion and 5,10,30 and 150 minutes after the end of infusion. Haemodynamic measurements were also made three minutes after the beginning of the infusion of cremophor EL. Cardiac output (CO) was measured by themal dilution with the use of a cardiac output computer (Hewlett-Packard). Three ml of five per cent dextrose in water (temperature $0-4^{\circ} \mathrm{C}$ ) were injected into the right atrium. $\mathrm{CO}$ was measured in triplicate and the average was used. Pulmonary capillary wedge pressure (PCWP) was measured. Systemic arterial pressure, pulmonary pressures and the pneumogram were recorded on a polygraph. The haemodynamic measurements were made at the end of expiration. Vascular resistances were calculated using usual formulae. Dynamic thoracopulmonary compliance (C) was calculated:

$\mathrm{C}=\frac{\text { tidal volume }(\mathrm{ml})}{\text { tracheal pressure }\left(\mathrm{cmH}_{2} \mathrm{O}\right)}$

In the second group (Group II, $\mathrm{n}=6$ ) cardiac output, systemic arterial pressure and blood volume were measured before the injection of cremophor EL, at the end of infusion and 10,30,90 and 150 minutes after the end of infusion. Plasma histamine and catecholamines were assayed before the injection of cremophor EL and 2, 5, $10,30,90$ and 150 minutes after starting the infusion. Blood volume and plasma volume were measured using the distribution of autologous red blood cells labelled with 51-chromate in accordance with the recommendations of the International Committee for Standardization in Hernatology. Blood samples were aliquoted into prechilled tubes containing one per cent (V/V) ethylenediamine-tetraacetic acid $\left(0.5 \mathrm{~mol} \cdot \mathrm{L}^{-1}\right)$ for histamine assay and into prechilled heparinized tubes for the assay of catecholamines. The tubes wcre kept on ice and centrifuged at $4^{\circ} \mathrm{C}$ within 30 minutes of sampling, and the supernatant was stored at $-80^{\circ} \mathrm{C}$ until assay. Plasma

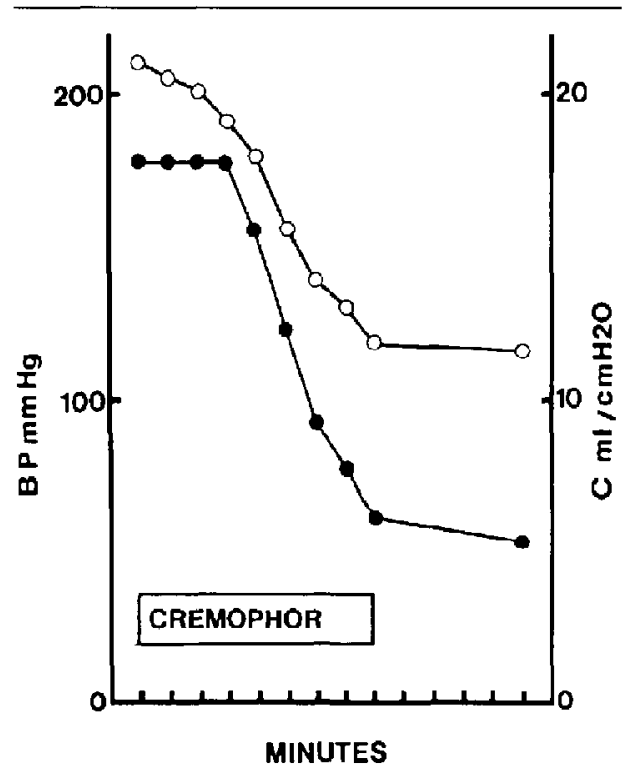

FGURE 1 Typical pattems of sysiolic arterial pressure, BP $\mathrm{mmH}_{3}$ (closed circles) and thoracopulmonary compliance, ml $\cdot \mathrm{cmH}_{2} \mathrm{O}^{-1}$ (open circles) during infusion of cremophor EL. Burs = minates

histamine was assayed using a double isotope radioenzymatic method ${ }^{9}$ with a sensitivity of $25 \mathrm{pg} \cdot \mathrm{ml}^{-1}$. Plasma epinephrine and norepinephrine were assayed using a double radio-enzymatic method ${ }^{10}$ with a sensitivity of $5 \mathrm{pg} \cdot \mathrm{ml}^{-1}$.

The data were analyzed by two-way analysis of yariance, followed by the studentized range test for multiple comparisons. ${ }^{11}$

\section{Results}

The expected drop in systemic arterial pressure occurred after infusion of the cremophor EL. In six dogs cutaneous erythema and oedema of the paws and muzzle were observed. All animals recovered without untoward problems.

\section{Group l - Systemic haemodynamics}

The haemodynamic pattern was highly reproducible (Figure 1). Systemic blood pressure began to fall after three to four minutes, with the maximum decrease occurring in six to eight minutes. Figure 2 shows the effects of cremophor EL on systemic haemodynamics. Systolic hlood pressure was markedly decreased at the end of the infusion of cremophor EL ( -68 per cent, $p<0.01$ ), and five and ten minutes after the end of infusion $(-7)$ per 


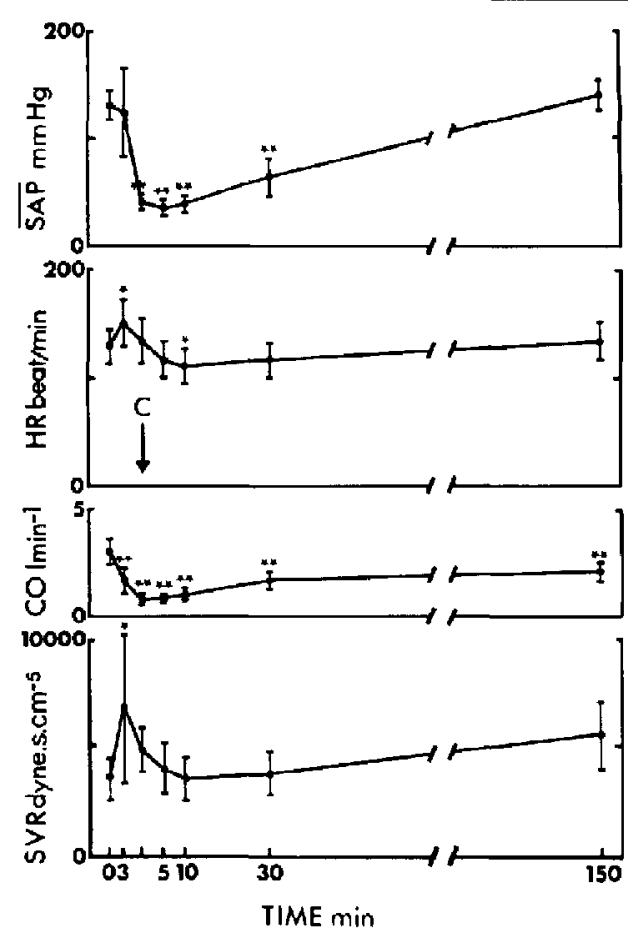

FIGURE 2 Group $\mathbf{I}, \mathbf{n}=7$. Mean ( \pm SD) systemic anterial pressure (SAP, mmHg), heart rate (beals/min), cardiac output ( $\mathrm{CO}, \mathrm{L} \cdot \mathrm{min}^{-1}$ ) and systemic vaseular resistances (SVR, dyne $\cdot \mathrm{s} \cdot \mathrm{cm}^{-5}$ ), beforc infusion of cremophor EL, at the end of infusion (C) and $5,10,30$ and I50 minutes after the end of infusion. $* p<0.05 ;{ }^{* *} p<0.01$.

cent, $\mathrm{p}<0.01$ and -70 per cent, $\mathrm{p}<0.01$ respectively). It then increased slowly $(-43$ per cent at the 30 th minute, $p<0.01)$. At 150 minutes it was slightly increased compared to basal values (+eight per cent, $\mathrm{p}<0.01$ ). Cardiac output decreased sharply and rapidly. This decrease was significant three minutes after the beginning of infusion ( -47 per cent, $F<0.01$ ), and very marked at the end of infusion $(-78$ per cent, $p<0.01)$. It then increased slowly but remained significantly lowered up to the 150th minute $(-32$ per cent, $\mathrm{p}<0.01)$. Heart rate increased slightly three minutes after the beginning of the infusion $(+18$ per cent, $p<0.01$ ), but did not differ from basal values at the end of infusion. Subsequently heart rate decreased slightly and this decrease was significant ten minutes after the end of infusion. Systemic vascular resistance increased markedly and significantly three minutes after the beginning of infusion ( +98 per cent, $\mathrm{p}<$ 0.05 ) but subsequently did not differ from basal values.

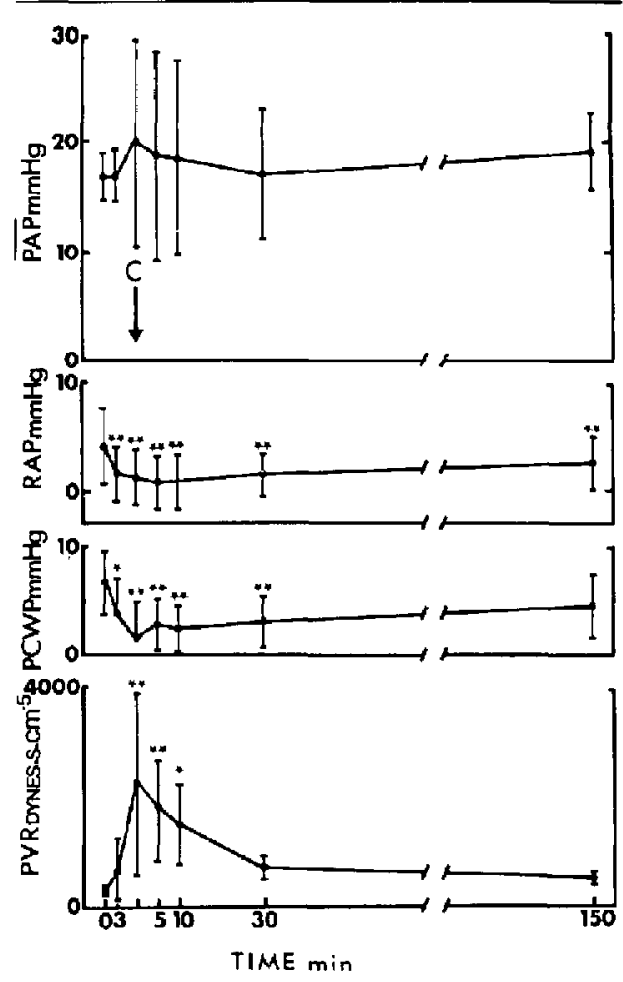

FlGURE 3 Group $\mathrm{I}, \mathrm{n}=7$. Mean ( \pm SD) pulmonary ancrial pressure ( $\mathrm{PAP}, \mathrm{mmHg}$ ), right alial pressure ( $\mathrm{RAP}, \mathrm{mmHg}$ ), pulmonary capillary wedge pressure ( $\mathrm{PCWF}, \mathrm{mmHg}$ ) and pulmonary vascular resistances (PVR, dyne $\cdot 5 \cdot \mathrm{cm}^{-5}$ ) hefore infusion of cremophor $\mathrm{EL}$ at the end of infusion (C) and S, 10,30 and 150 minutes after the end of infusion. ${ }^{*} p<0.05 ;{ }^{* *} p<0.01$.

\section{Pulmonary haemodynamics}

Figure 3 shows the effects of cremophor EL on pulmonary haemodynamics. Pulmonary arterial pressure did not vary significantly. Right atrial pressure and capillary pulmonary pressure decreased significantly three minutes after the beginning of infusion, at the end of infusion and $5,10,30$ and 150 minutes after the end of infusion. Pulmonary vascular resistances increased markedly and significantly at the end of infusion and five and ten minutes after the end of infusion $(+734$ per cent, $\mathbf{p}<$ $0.01 ;+548$ per cent, $\mathrm{p}<0.01 ;+439$ per cent, $\mathrm{p}<$ 0.01 , respectively).

\section{Thoracopulmonary compliance}

Figure 4 shows the effects of cremophor EL on dynamic thoracopulmonary compliance. Compliance decreased 


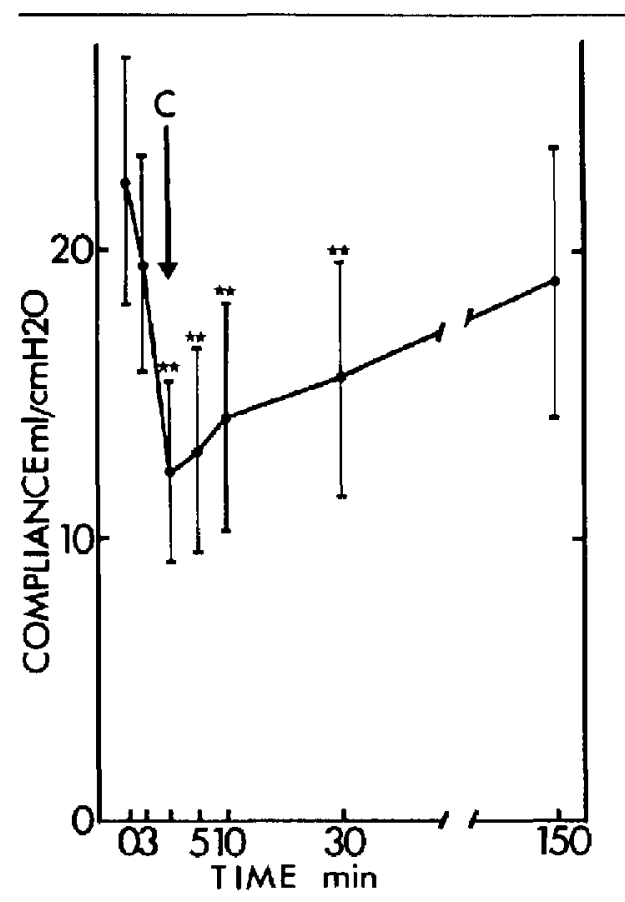

FiGURE 4 Group $I, n=7$. Mean ( \pm SD) thoracopulmonary compliance (ml $\cdot \mathrm{cms}_{2} \mathrm{O}^{-1}$ ) before the infusion of cremophor $\mathrm{EL}$, at the end of infusion (C) and 5,10, 30 and 150 minutes after the end of infusion. ** $p<0.01$,

rapidly and was markedly decreased at the end of infusion $(-46$ per cent, $p<0.01)$. Subsequently, it increased slowly and it did not differ from basal values at 150 minutes.

\section{Haematological changes}

Figure 5 shows the haematological changes induced by cremophor EL. Haematocrit increased significantly at the end of infusion and reached maximum values 150 minutes after the end of infusion $(+23$ per cent, $p<$ $0.01)$. The platelet count decreased sharply and significantly at the end of infusion, then increased slowly, Values at 150 minutes did not differ significantly from basal values. The leucocyte count followed the same general profile except that at 150 minutes there was a significant increase $(+60$ per cent, $p<0.01)$.

Group II - Systemic haemodynamics

The effects of cremophor EL on arterial blood pressure,

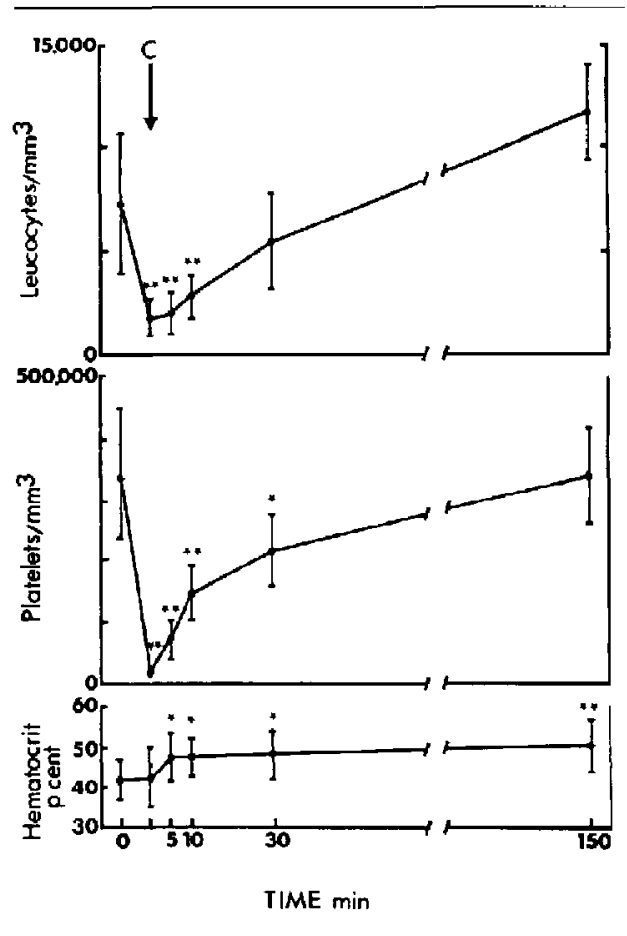

FIGURE 5 Group ], $\mathrm{n}=7$. Mean ( \pm SD) leucocyte count $/ \mathrm{mm}^{3}$, platelet count $/ \mathrm{mm}^{3}$ and haematocrit (per cent) before the injection of cremophor $E L$, at the end of infusion (C) and 5, 10, 30 and 150 minutes after the end of infusion. ${ }^{*} p<0.05 ;{ }^{*} p<0.01$.

heart rate and cardiac output were the same as in Group 1.

\section{Plasma histamine and catecholamines}

The table shows the changes in plasma histamine and catecholamines. Plasma histamine increased sharply after cremophor EL administration, reaching maximum values at 10 minutes $(+1214$ per cent, $p<0.001)$. At 150 minutes the plasma histamine level was nearly double basal values. Plasma epinephrine and norepinephrine rose concommitantly $(+816$ per cent and +200 per cent respectively at ten minutes).

\section{Blood volume}

Figure 6 shows the effects of cremophor EL on blood volume. Blood volume decreased significantly at ten minutes and 30 minutes $(-17.7$ per cent, $\mathrm{p}<0.05$; -19.5 per cent, $p<0.02$, respectively). This decrease 

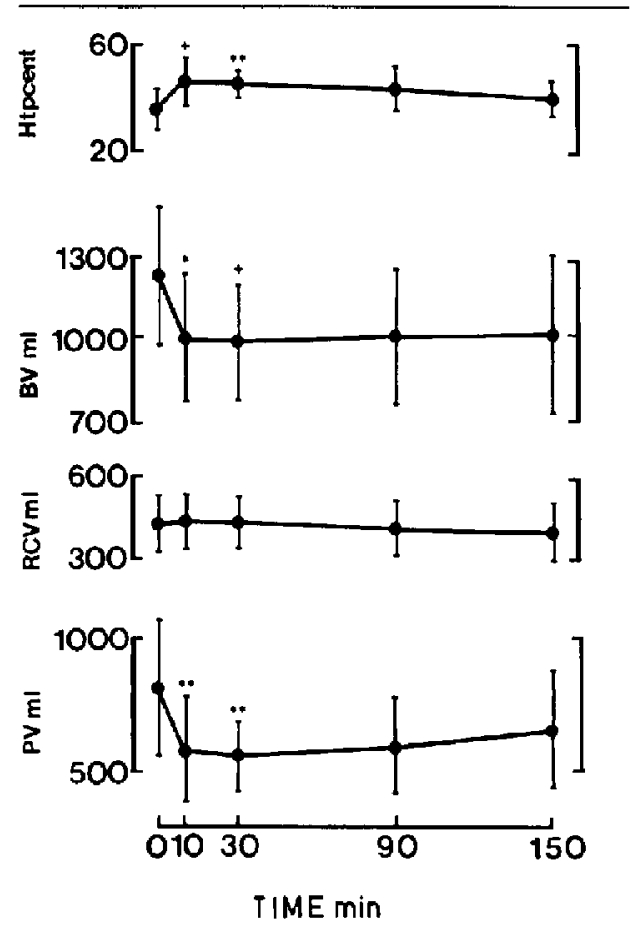

FIGURE 6 Group Il, $n=6$. Mean ( \pm SD) haematocrit (per cent), blood volume $(\mathrm{BV}, \mathrm{ml})$, red cell volume $(\mathrm{RCV}, \mathrm{ml})$, and plesma volume $(\mathrm{PV}, \mathrm{ml})$, before the injection of cremophor $\mathrm{EL}$ and $10,30,90$ and 150 minutes after the beginning of infusion. $t p<0.02 ; *<0.05$; ${ }^{* *} \mathrm{p}<0.01$. was due to a decrease in plasma volume ( -28 per cent, $\mathrm{p}<0.05 ;-30.5$ per cent, $\mathrm{p}<0.05$ respectively).

\section{Discussion}

Cremophor EL is used as a solvent for various drugs used as anaesthetics (althesin, propanidid, diazepam), steroids and vitamins (A, D, E, K.1). Although althesin has now been withdrawn, cremophor EL is still widely used. Cardiovascular collapse has been reported with althesin and propanidid in man, ${ }^{12}$ and thought to be due to the solvent cremophor EL. A proportion of these reactions has been encountered on the first administration of the agents. The effects of cremophor EL have not been extensively studied. Glen et al. ${ }^{7}$ proposed a pig model for the study of adverse reactions to anaesthetics and their solvents. However, the responses noted in pigs differ greatly from those associated with adverse reactions in man in that bronchospasm is not a feature of the reaction and marked hypertension rather than hypotension is a constant finding. The dog model has been proposed by Lorenz et al..$^{8}$ principally for the study of histamine release.

The results of the present study confirm the observations of Lorenz $\mathrm{et} \mathrm{al.}{ }^{8}$ They show that the dog model can be used in studying anaphylactoid reactions. In fact, reactions observed in dogs after administration of cremophor EL are very similar to reactions reported in man during anaphylactic or anaphylactoid reactions. The clinical effects of cremophor EL observed in the present study have previously been reported with cremophorcontaining drugs, mainly althesin, in dogs. ${ }^{13,14}$ In all our dogs cremophor EL induced severe cardiovascular collapse, with a significant and protracted decrease in blood

TABI.F. Results. Plasma histamine, epinephrine and norepinephrine (mean \pm SD) before (time 0 ) and after cremophor infusion. (Group $I I, n=6$. Mean \pm SD

\begin{tabular}{|c|c|c|c|c|c|c|c|}
\hline \multicolumn{8}{|c|}{ Histamine $\left(n g \cdot m t^{-1}\right)$} \\
\hline & $0.63 \pm 0.10$ & $200.65 \pm 490.07$ & $7703.8 \pm 4276.1$ & $77141.8 \pm 9717.6$ & $15956.8 \pm 13728.3$ & $2231.4 \pm 2582.4$ & $960.75 \pm 805.46$ \\
\hline $\mathrm{p}$ & & NS & 0.01 & 0.001 & 0.05 & NS & 0.05 \\
\hline \multicolumn{8}{|c|}{ Norepinephrine (ng $\mathrm{ml}^{-1}$ ) } \\
\hline$p$ & & NS & NS & 0.01 & 0.01 & 0.05 & NS \\
\hline \multicolumn{8}{|c|}{ Epinephrine $\left(n g \cdot n l^{-i}\right)$} \\
\hline & $0.12 \pm 0.05$ & $0.11 \pm 0.06$ & $0.21 \pm 0.11$ & $1017.9 \pm 929.1$ & $666.2 \pm 1159.4$ & $0.38 \pm 0.33$ & $0.16 \pm 0.11$ \\
\hline$p$ & & NS & NS & 0.05 & NS & NS & NS \\
\hline
\end{tabular}


pressure and cardiac output, associated with a massive increase in plasma histamine and catecholamines, Of the various mast cell-derived mediators released during anaphylactic and/or anaphylactoid shock (histamine, serotonin, leucotrienes, platelet activating factor, etc.) histamine is at present the most easily assayable in plasma. Plasma histamine levels can be considered a good marker of mast cell degranulation. ${ }^{15}$ Our data show that cremophor-induced cardiovascular collapse is associated with a large increase in histamine, thus indicating acute mast cell degranulation. The observed nise in plasma epinephrine and norepinephrine is likely due to baroreflex stimulation of the sympathoadrenal system due to hypotension, ${ }^{16,17}$ and may contribute to the secondary decrease in plasma histamine. ${ }^{18-20} \mathrm{Histamine}$ and catecholamines release has previously been reported during anaphylactoid reactions in the rat ${ }^{21}$ and during anaphylactic and anaphylactoid reactions induced by succinylcholine $\mathrm{e}^{22}$ and morphine ${ }^{23}$ in man.

In man, due to the unpredictable and dramatic nature of anaphylactic and/or anaphylactoid reactions, there have been few complete haemodynamic studies. Moss et al. ${ }^{22}$ reported one case of an anaphylactic reaction three minutes after administration of succinylcholine. Heart rate increased dramatically, but cardiac output and systemic vascular resistances remained unchanged. There was massive release of histamine and catecholamines. Carlson et al. ${ }^{24}$ reported a case of non-cardiogenic pulmonary oedema with hypotension and low cardiac filling pressures associated with anaphylaxis. In the case reported by Fisher ${ }^{25}$ hypotension was due to hypovolemia. Symons et $a l^{26}$ reported two cases of anaphylactoid reactions to vancomycin with an increase in systemic and pulmonary capillary permeability. In the report by Silverman et $a .^{27}$ of an anaphylactic reaction to penicillin, there was a decrease in arterial pressure, cardiac output, and capi]. lary pulmonary wedge pressure, and an increase in peak airway pressure, pulmonary vascular resistance and systemic vascular resistance. Ponten et al. ${ }^{28}$ recently reported a reaction to thiopentone, associating cardiovascular collapse and non-cardiogenic oedema.

The effects of cremophor EL on systemic and pulmonary haemodynamics observed in our dogs are similar to the few haemodynamic studies made in man. They are also similar to the results reported by Enjeti et al ${ }^{29}$ in anaesthetized and artificially ventilated dogs during antigeninduced anaphylactic reactions. These reactions were accompanied by a decrease in systemic arterial pressure, cardiac output, and right and left atrial pressures, without significant changes in pulmonary arterial pressure and heart rate. These authors attributed the fall in cardiac output to blood pooling in the splanchnic circulation, extravasation of plasma playing a secondary role in their model of anaphylactic shock.

In our dogs, the initial haemodynamic modifications were probably also due to splanchnic pooling, resulting in decreased venous return. However, as in man, ${ }^{25,30}$ subsequent hypovolemia related to extravasation of plasma was undoubtedly an important mechanism explaining the prolonged decrease in blood pressure and cardiac output. The main haemodynamic difference between man and dog is the alteration in heart rate. In man, tachycardia is frequently reported during anaphylactic or anaphylactoid reactions. In the present study there was a slight increase in heart rate three minutes after the start of the infusion of cremophor EL, and a slight decrease ten minutes after the end of infusion. This absence of tachycardia has previously been reported in anaeschetized dogs during anaphylactic shock. ${ }^{29,31}$ It should be noted that in non-anaesthetized dogs anaphylactic shock induces tachycardia. ${ }^{32}$

In man, respiratory disturbances seen during anaphylactoid and/or anaphylactic reactions are primarily bronchospasm, and less frequently pulmonary oedema. ${ }^{25-28}$ In the monkey, Revenas et al. ${ }^{33}$ showed that during antigen-induced anaphylaxis dynamic compliance was decreased as a result of constriction of small airways and pulmonary congestion. In the present study, the injection of cremophor $\mathrm{EL}$ resulted in a significant and persistent decrease in dynamic thoracopulmonary compliance. This decrease occurred early, before the fall in systemic arterial pressure (Figure 1). Dynamic compliance depends on both airway resistance and static properties of the respiratory system. In the present study, neither airway resistance nor static compliance were measured. It is possible that both are modified during anaphylactoid reaction induced by cremophor EL. However, the rapid decrease in dynamic compliance and the rapid increase in tracheal pressure are more consistent with an increase in airway resistance than with a decrease in pulmonary compliance, for example due to pulmonary oedema caused by extravasation of plasma, which is a late event. It is also possible that halothane produced bronchodilation, ${ }^{34}$ reducing the bronchoconstriction effect of the cremophor EL.

Haematological changes have been described during anaphylactic and/or anaphylactoid reactions. Cellular changes during administration of althesin occur even in the absence of clinical signs. ${ }^{35}$ Platelet aggregation is a well-documented phenomenon in shock, sepsis and trauma. In anaphylactic shock, extensive platelet aggregation was associated with a marked drop in platelet count within five minutes. ${ }^{36}$ The platelet count rose progressively during the next 90 minutes. It is quite possible 
that, as in canine endotoxin shock, ${ }^{37}$ platelet aggregation plays an important role in the pulmonary response observed in the present study.

The results of the present study show that cremophorinduced shock is of the anaphylactoid type, and includes cutaneous erythema and oedema, hypotension, venous pooling, plasma extravasation, histamine and catecholamine release, and decreases in dynamic thoracopulmonary compliance and leucocyte and platelet counts. This model could be used in studying anaphylactoid reactions and their prevention and treatment.

\section{Acknowledgements}

The authors thank I. Litwin, D. Vergoz, C. Sabatier and J. Carabasse for the biolngical measurements.

\section{References}

1 Sroelting RK. Allergic reactions during anesthesia. Anesth Analg 1983; 62: 341 .

2 Adverse responses to intravenous drugs. Watkins $J A$, Ward AM (Eds). London: Academic Press 1978.

3 Adverse reactions to anaesthetic drugs. Thomton JA ed. Monographs in anaesthesiology. Vol 8. Amsterdam. Excerpta Medica, Elsevier North-Holland Biomedical Press 1981.

4 Adverse reactions. Clinics in Anesthesiology. Vol 2, No. 3, WB Saunders Company, London 1984.

5 Anaphylactoid reactions in anesthesia. Sage DE ed. International Anesthesiology Clinics. Vol 23, No. 3, 1985.

6 Watkins J, Wild G, Clarke RSJ. Allergy, plasma IgE level and anaphylactoid responses: a hypothesis. Anaesthesia 1985; 40: 362 .

7 Glen JB, Davies GE, Thompson DS, Scarth SC. Thompson $A V$. An animal model for the investigation of adverse responses to anaesthetic agents and their solvents. $\mathrm{Br} \mathrm{J}$ Anaesth 1979; 51:819.

8 Lorenz W. Schmal A, Schult $H$, et al. Histamine release and fatty acids: analysis of various components in cremophor EL and development of a compound with reduced toxicity. Agents and Actions 1982; $12: 64$.

9 Brown MJ, Ind PN, Causon R, Lee THA. A novel doubleisotope technique for the enzymatic assay of plasma histamine: application to estimation of mast cell activation assessed by antigen challenge in asthmatics. J Allergy Clin Immunol 1982; 69: 20 .

10 Brown MJ. Jenner DA. Novel double-isotope technique for enzymatic assay of plasma catecholamines, permitting high precision, sensitivity and plasma sample capacity. Clin Sci 1981; 61: 591

11 Lellouch J. Lazar $P$. Méthodes statistiques en expérimentation biologique. Flammarion. Paris. 1974, p. 147.
12 Clarke RSJ. Adverse effects of intravenously administered drugs used in anesthetic practice. Drugs 1981: 22: 26.

13 Child KJ, Currie JP, Davis B, Dotds MG, Pearce DR, Twissel $D J$. The pharmacological properties of CT 1341 in animals, a new anaesthetic agent. Br J Anaesth 1971; 43: 2.

14 Gaudy $J H$, Dauthier $C$, Boitier JF, Ferracei F, Effets ventilatoires de débits croissants d'Alfatésine chez le chien. Can Anaesth Soc J 1982; 29: 600

15 Barnes PI, Brown MJ. Venous plasma histamine in exercise and hyperventilation-induced asthma in man. Clin Sci 1981; 61: 159 .

16 Owen DAA. Histamine-induced changes in heart rate in anaesthetized cat. Br J Pharmacol 1977; 60: 285.

17 Lin MS, McNay SL, Schepperd AM, Keeton TK. Effects of hydralaxine and sodium nitroprusside on plasma catecholamines and beart rate. Clin Pharmacol Ther 1983; 34: 474 .

18 Butchers PR, Fularion IR, Skidmore IF, Thompson LE, Vurdey $C J$, Wheedom AA. A comparison of the antianaphylactic activities of salbutamol and disodium cromoglycare in the rat, the rat mast cell and in human lung tissues. Br J Pharmacal 1979; 67: 23.

19 Church $M K$, Young KD. The characteristics of inhibition of histamine release from human lung fragments by sodium cromoglycate, salbutamol and chlorpromazine. $\mathrm{Br}$ J Pharmacol 1983; 78: 671.

20 Barnes P, Fitzgerald G, Brown M, Dollerey CT. Noctur nal asthma and changes in circulatory epinephrine, histamine and cortisol. N Engl J Med 1980; 303: 263.

21 Hamberger B, Fredholm BB, Farbero LO. Anaphylaxis and plasma catecholamines. Life Sci 1980; 26: 1465.

22 Moss J, Fahmy NR, Sunder N, Beaven MA. Hormonal and hemodynamic profile of an anaphylactic reaction in man. Circulation 1981; 63: 210.

23 Fahmy NR. Hemodynamics, plasma histamine and catecholamines concentrations during an anaphylactoid reaction to morphine. Anesthesiology 1981; 55: 329.

24 Carlson RW, Schaeffer RC, Puri VK, Brennan AP, Weil $M H$. Hypovolenia and permeability edema associated with anaphylaxis. Crit Care Med 1981; 9: 883.

25 Fisher MM. Blood volume replacement in acute anaphylactic collapse related to anaesthesia. Br J Anaesth 1977; 49: 1023.

26 Symons NLP, Hobbes AFT, Leaver HK. Anaphylactoid reactions to vanomycin during anaesthesia: two clinical Teports. Can Anaesth Soc J 1985; 32: 178.

27 Silverman HJ, Van Hook Ch, Haponik EF. Hemodynamic changes in human anaphylaxis. Am J Med 1984; 77: 341 .

28 Ponten J, Biber $B$, Henrikson BA. Successful vasoconstrictor therapy of anaphylactoid reactions during induction of anaesthesia. A report of two cases. Acta Anaesthesiol Scand $1985 ; 29: 555$. 
29 Enjeti S, Bleeker ER, Smith PL, Rabson J, Permutt $S$, Traystman $J$. Hemodynamic mechanisms in anaphylaxis. Circulatory Shock 1983; 11:297.

30 Clarke RSI. The clinical presentation of anaphylactoid reactions in anesthesia. Int Ancsthesiol Clin 1985; 23 : 1.

31 Spizzer JJ. Myocardial substrate utilization in anaphylactic shock. Proceedings of the Society of Experimental Biology and Medicine 1976; 151: 28.

32 Spizzer JJ. Metabolic changes in dogs during anaphylactic shock. Life Sci 1976; 17: 1855.

33 Revenäs $B$, Smedegärd $G$, Affors KE. Anaphylaxis in the monkey: respiratory mechanics, acid-base status and blood gases. Acta Anaesthesiol Scand 1979; 23: 278 .

34 Hirshman CA. Perioperative management of the patient with asthma. An.esth Analg 1984; 63: 278.

35 Wakkins J, Udnoon S, Taussig P. Mechanisms of adverse reactions to intravenous agents in man. $I n$ : Adverse responses to intravenous drugs. Watkins JA, Ward $A M$, eds, London. Academic Press, pp 71-82, 1978.

36 Robb HJ. Observations on dynamies of microcirculation during experimental anaphylaxis. Ann Allergy 1967; 25; 78.

37 Bredenberger CE, Taylor GA, Webb WR. The effect of thrombocytemia on the pulmonary and systemic hemodynamics of canine endotoxin shock. Surgery 1980; 87: 59.
Résumé

Les effets du crémophor EL ont été étudiès chez 13 chiens anesthésiés, curarisés et ventilés artificiellement. $4.3 \pm 0.92 \mathrm{ml}$ de crémophor a 20 pour cent ont été injectés à la vitesse de 30 milheure. Chez sept chiens, la compliance thoracopulmanaire. la fréquence cardiaque, la pression artérielle systémique (SAP), les pression pulmonaires (PAP, PCWP, RAP), le débit cardiaque (CO), les plaquettes et les leucocytes, ont été mesurés avant l'injection de crémophor $E L$, da la fin de l'injection et $5,10,30$ er 150 minutes après la fin de l'injection. Chez six chiens, SAP, CO et la masse sanguine ont êté mesurés avant l'injection de crémophor EL et 10,30, 90 et 150 minutes après la fin de l'injection. Lhistamine et les catécholamistes plasmatiques furent mesurées avant l'injection de crémophor EL et 2, 5, 10,30, 90 et 150 minutes après le début de i'injection.

Le crémophor EL provoqua une diminuson importante, durable et significative de SAP a la fin de l'injection, 5, 10 et 30 minutes après la fin de l'injection (respectivement, $-68,-71$, -70 et -43 pour cent), de PCWP, de RAP at de CO $(-78$ pour cent à la fin de l'injection, -32 pour cent 150 minutes après la fin de l'injection). La fréquence cardiaque et les résistances vasculaires systémiques ne varièrent pas significativement. Les résistances vasculaires pulmonaires augmentè. rent à la fin de l'injection, cinq et dix minutes après la fin de l'injection (respectivement $+734,+548$ et +439 pour cent). Le volume plasmatique diminua 10 et 30 minutes après la fin de l'injection (respectivement -28 et -30.5 pour cent). La compliance thoracopulmonaire diminua ( -46 pour cent da la fin de l'injection). Les plaquetres et les leucocyles diminuèrent fortement. I y eut une augmentation très importante et durable de l'histamine plasmatique $(+1214$ pour cent dix minutes apres le débul de l'injection) et des carécholamines plasmatiques. Chez six chiens un érythèrte cutané et un cedème des pattes et du museau furent observés.

Ces effets sont très praches des phenomènes rapportés chez I'homme au cours d'accidents anaphylactiques etlou anaphylactoides. Ce modèle pourrait être utilisé pour l'étude des réac. tions anaphylactoides. de leur prêvention et de leur traitement. 